\title{
PREDSTAVLJANJE KNJIGE PROF. DR. SC. IVANA KOPRIĆA "USPAVANO SRCE DEMOKRACIJE: LOKALNA SAMOUPRAVA ZA GRAĐANE I ZAJEDNICU”
}

Katedra za ustavno i europsko pravo Pravnog fakulteta Sveučilišta J. J. Strossmayera u Osijeku organizirala je predstavljanje knjige prof. dr. sc. Ivana Koprića, redovitog profesora u trajnom zvanju Pravnog fakulteta Sveučilišta u Zagrebu, predstojnika Katedre za upravnu znanost pod nazivom "Uspavano srce demokracije: lokalna samouprava za građane i zajednicu" iz 2018. godine. Predstavljanje je održano u utorak, 14. svibnja 2019. u 19:00 sati na Pravnom fakultetu u Osijeku.

U uvodnom dijelu, moderatorica manifestacije izv. prof. dr. sc. Anita Blagojević (Katedra za ustavno i europsko pravo) pozdravila je cijenjenoga gosta i istaknutog znanstvenika, uvodničare predstavljanja knjige te publiku. Sve prisutne u ime dekanice Pravnog fakulteta u Osijeku pozdravio je prodekan za poslovanje, razvoj i projekte doc. dr. sc. Mato Palić (Katedra za ustavno i europsko pravo). Zatim je prof. dr. sc. Boris Bakota (Katedra za upravno pravo i znanost) iskazao veliko zadovoljstvo u povodu dolaska cijenjenog profesora te ukazao na značaj suradnje, kontakta i dijaloga između svih članova Katedre koje osobito potiče prof. Koprić. Ukratko je predstavio izniman znanstveni rad, znanstvena postignuća i doprinos akademskoj zajednici i praksi upravnog stručnjaka prof. Koprića u području javne uprave, upravnog prava i osobito upravne znanosti. Određene sličnosti i povezanost u znanstvenom djelovanju, ali i poneke životne podudarnosti s prof. Koprićem istaknuo je u svom govoru dr. sc. Zvonimir Lauc, umirovljeni profesor emeritus Pravnog fakulteta Osijek.

Nakon uvodnih govora, publici se obratio prof. Koprić i zahvalio na pozivu. Objasnio je početnu ideju i zamisao te pojasnio razloge pisanja, osmišljavanja, poticaja i inicijative za tiskanje navedene knjige od strane gosp. Franje Simića (koji ga je ujedno i pozvao da piše kolumne o aktualnim temama iz područja javne uprave za Vrbovečke novine). Valja istaknuti kao je sve započelo 2000. godine u povodu ideje novinara Simića o redovnim radijskim gostovanjima profesora Koprića (tadašnjeg Vladina povjerenika za Vrbovec). Cilj je tih razgovora bio upoznati Vrbovčane o aktualnim pitanjima u vezi s gradskom upravom i politikom. Službeno poznanstvo razvilo se i preraslo u uspješnu suradnju na dobrobit Vrbovčana. Nadalje, prof. Koprić ukazao je na razloge odabira nakladnika udruge Avis Rara Studio. Kako je i u samoj knjizi navedeno, počela je nastajati u atmosferi europskog entuzijazma 2012. godine. Riječ je o jednom specifičnom i sadržajno drukčijem izdanju namijenjenom ciljanoj publici. Posrijedi je dakle knjiga koja se sastoji od 52 kolumne iz Vrbovečkih novina u razdoblju od 2012. do 2018. godine, 11 tekstova objavljenih u drugim medijima i popis radijskih emisija iz 2013. godine, kao i neobjavljenom radu prof. Koprića "Uspavano srce demokracije". Kolumne su vezane za aktualnu tematiku iz područja (reforme) lokalne samouprave, reforme javne uprave, decen-

Dr. sc. Ana Đanić Čeko, docentica na Katedri za upravno pravo i znanost Pravnog fakulteta Sveučilišta Josipa Jurja Strossmayera u Osijeku. Stjepana Radića 13, 31000 Osijek. Adresa e-pošte: adjanic@pravos.hr. 
tralizacije, potrebe teritorijalnog preustroja, problema teritorijalne rascjepkanosti i brojnim drugim.

U završnom dijelu predstavljanja svoje knjige, profesor je odgovarao na pitanja publike i još jedanput zahvalio na pozivu. Poslužila bih se odabranim promišljanjima predgovora i citirala: "Unatoč tome što na lokalnoj razini postoje ukorijenjene lokalne zajednice, hrvatska lokalna samouprava ostaje uspavana. Hrvatska lokalna samouprava mogla bi biti ljepotica divnog glasa, ali se ubola na opasno vreteno centralizma i općeg nehaja prema demokratskim standardima..." 